\title{
Meningokoksemide Erken Agresif Tedavinin Önemi: Dört Vakanin Sunumu
}

\section{The Significance of Early Aggressive Treatment of Meningococcemia: \\ Presentation of Four Cases}

Bahri Elmas', Nihat Atahan Kanbur', Öner Özdemir²

1 Sakarya Üniversitesi Tıp Fakültesi Pediatri Anabilim Dalı, Sakarya Sakarya Üniversitesi Tip Fakültesi Pediatri Anabilim Dalı, Pediatrik Alerji Bilim Dalı, Sakarya

Correspondence / Yazışma Adresi:

\section{Yrd. Doç. Dr. Bahri ELMAS}

Sakarya Üniversitesi Tıp Fakültesi Pediatri AD, Sakarya

P: :+90 5335505351

Geliş Tarihi / Received : 26.04.2017

E-mail: bahrielmas@gmail.com

Kabul Tarihi / Accepted : 24.05.2017

\section{Özet}

Meningokoksemi; purpura fulminans, septik şok ve çoklu organ yetmezliğine neden olabilen özellikle küçük çocuklarda mortalitesi çok yüksek bir hastalıktır. Erken tanı konularak yoğun tedavi uygulanması önemlidir. Bu yazıda meninkoksemi nedeni ile takip ve tedavi edilen dört vaka tartışılmıștı. íki vaka erken agresif tedavi ile tamamen düzelirken bir vaka yaklașık üç saatlik bir gecikme nedeni ile tedaviye cevap alınamayarak ex olmuș, bir vaka iki parmak ampütasyonu ile iyileșmiștir. Erken tanı ve agresif tedavi uygulanan hastalarda mortalite önlenebilmektedir. Ateş ve bilinç değişikliği nedeni ile başvuran ve şok bulguları tespit edilen hastalarda döküntü de bulunması durumunda meningokoksemi düşünülerek erken agresif tedavi başlanması hayati önem taşımaktadır. ( Sakarya Tıp Dergisi 2017, 7(2):105-108 ).

Anahtar Kelimeler: Erken agresif tedavi, meningokoksemi)

\section{Abstract}

Meningococcemia is characterized by purpura fulminans, septic shock, and multiple organ failure, and mortality is especially high in young children. It is important early diagnosis and intensive treatment. In this article, four cases followed and treated with the diagnosis of meningoxemia were discussed.Two cases were fully improved with early aggressive treatment,whereas one case died due to late admission, and one case was improved with two finger amputations. Mortality can be avoided in patients with early diagnosis and aggressive treatment. It is vitally important to initiate early aggressive treatment for meningococcemia if a rash is present in patients with a history of fever and altered consciousness and in whom shock findings are detected. ( Sakarya Med J 2017, 7(2):105-108 )

Keywords Early aggressive treatment, meningococcemia 


\section{Giriş ve Amaç}

Neisseria meningitidis invaziv meningokokal enfeksiyonlara yol açabilen anaerobik gram negatif diplokoktur ${ }^{1,2}$. Kapsüler polisakkaritlerinin immünohistokimysal boyanmasına göre 13 serogruba ayrılmaktadır. İnvaziv meningokokal hastalıklardan ise sıklıkla A, B, C, W-135, Y ve X serogrupları sorumludur ${ }^{3}$. İnsan nazofarinksi bilinen tek rezervuarıdır ve insandan insana, direkt temasla veya solunum yollarından damlacıklarla bulaşır ${ }^{4}$.

Nazofarinkste asemptomatik kolonizasyon yapabileceği gibi mukoza invazyonu yaparak meningokoksemi ve/veya menenjite de neden olabilir ${ }^{5}$. Meningokoksemi; purpura fulminans, septik şok ve çoklu organ yetmezliğine neden olabilen, ekstravasküler tromboz ve gangrenle karakterize, özellikle küçük çocuklarda mortalitesi çok yüksek bir hastalıktır ${ }^{6}$. Tedavide en önemli noktalar erken başlanan antibiyotik ve uygulanacak destek tedavileridir?

Çalışmamızda meningokoksemi tanısıyla izlenen dört vakanın takip ve tedavileri tartışılarak, agresif tedavi yaklaşımının öneminin vurgulanması amaçlanmıştır.

\section{Birinci olgu:}

Ateş ve kusma nedeni ile başvuru sonrası AGE tanısı ile ayaktan tedavi edilerek taburcu edilen ve yaklaşık 3 saat sonra döküntü nedeni ile yeniden başvuran 17 aylık kız hastada meningokoksemi düşünüldü. Fizik muayenede genel durumu kötü, perioral siyanozu mevcut, bilinci kapalı, sadece ağrılı uyaranlara cevabı vardı. Ateş $38,4^{\circ} \mathrm{C}$, kalp tepe atımı $172 / \mathrm{dk}$, solunum sayısı $74 / \mathrm{dk}$, tansiyon arteriyel alınamıyor ve kapiller dolum zamanı 5 sn idi. Tüm vücudunda yaygın peteşiyel döküntüler ve kutis marmoratus mevcuttu. Meningokoksemi ve septik şok düşünülerek $20 \mathrm{ml} / \mathrm{kg}$ dan $3 \mathrm{kez}$ serum fizyolojik intravenöz bolus olarak verildi. Seftriakson, metilprednizolon, taze donmuş plazma, $\mathrm{K}$ vitamini, dopamin, adrenalin ve noradrenalin infüzyon tedavileri verilmesine rağmen 4 saat içerisinde exitus oldu.

\section{ikinci olgu:}

Dokuz aylık erkek hasta, gün içerisinde devam eden ateş ve nefes darlığı şikayetiyle getirildi. Fizik muayenede genel durumu kötü, solunumu sıkıntllı, alt ekstremitelerde tek tük peteşiyal lezyonları mevcut idi. Ateş $36,7^{\circ} \mathrm{C}$, kalp tepe atımı $186 / \mathrm{dk}$, solunum sayısı $70 / \mathrm{dk}$, tansiyon arteriyel $113 / 53 \mathrm{mmHg}$ ve kapiller dolum zamanı 4 sn idi. Meningokoksemi ön tanısıyla yoğun bakım ünitesine yatırıldı. ỉki kez $20 \mathrm{ml} / \mathrm{kg}$ dan SF intravenöz bolus olarak verildi. Entübe edilerek seftriakson, deksametazon, taze donmuş plazma, K vitamini, heparin, albümin ve adrenalin tedavileri verildi. Takiplerinde tansiyon arteriyel değerleri normal değerlerde seyretti. Destek tedavilerine devam edilen hasta 3. düzey yoğun bakım şartları olan ileri bir merkeze sevk edildi ve sağ el baş parmak distal falanks amputasyonu ile taburcu edildi.

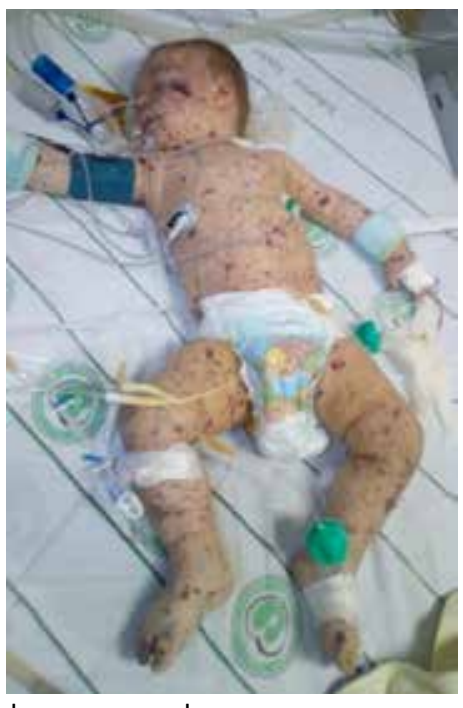

başvuru sırasında

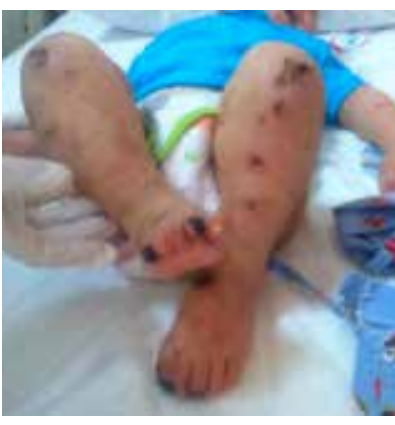

ayak parmağında nekroz

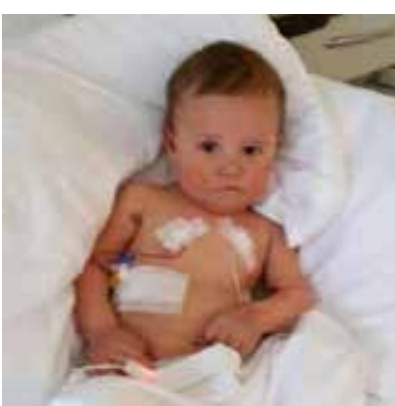

\section{Üçïncü olgu:}

Dört yaşında erkek hasta, birkaç saat önce başlayan ateş, döküntü ve uyku hali nedeniyle acil servisimize başvurdu. Fizik muayenede bilinç hafif uykuya meyilli olan hastanın peteşiyel döküntülerinin saptanması üzerine meningokoksemi ön tanısı düşünülerek yoğun bakım ünitemize yatıııldı. Ateş $36,4^{\circ} \mathrm{C}$, kalp tepe atımı $160 / \mathrm{dk}$, solunum sayısı $29 / \mathrm{dk}$, tansiyon arteriyel $77 / 35 \mathrm{mmHg}$ ve kapiller dolum zamanı 3 sn idi. Üç kez SF $20 \mathrm{ml} / \mathrm{kg}$ dan intravenöz bolus olarak verildi. Metilprednizolon, TDP, $\mathrm{K}$ vitamini, dopamin ve adrenalin destek tedavileri verildi. Takiplerinde genel durumu düzelen hasta şifa ile taburcu edildi. 


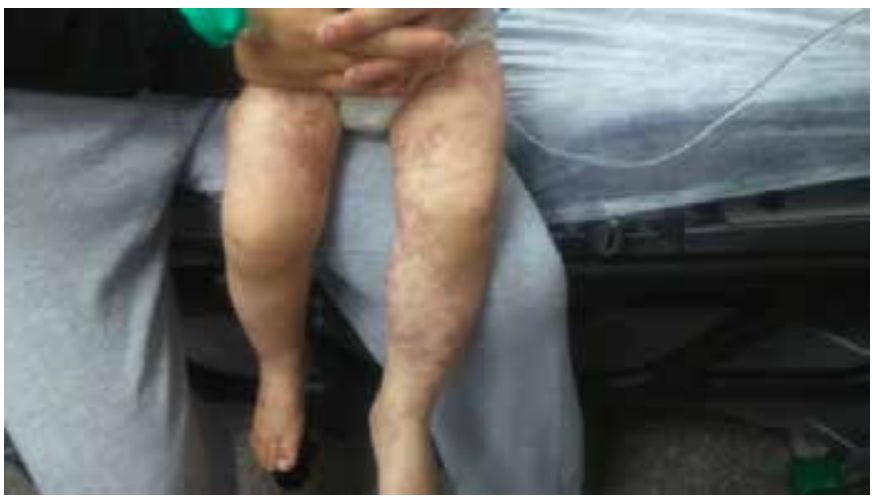

Başvuru anında ekimoza dönen yaygın kutis marmoratus

\section{Dördüncü olgu:}

İki gündür devam eden ateş ve kusmaları olan 11 yaşında erkek hastanın bilincinin kapanması nedeni ile getirildi. Ateş: $38^{\circ} \mathrm{C}$, kalp tepe atımı 160/dk, solunum sayısı 45/dk, tansiyon arteriyel 80/60 mmHg ve kapiller dolum zamanı 3 sn idi. Alt ekstremitede bir kaç adet peteşiyel döküntü görülmesi üzerine meningokoksemi düşünülerek 3 kez $20 \mathrm{ml} / \mathrm{kg}$ dan SF iv olarak puşelendi. Kan kültürü allnarak seftriakson, deksametazon, $\mathrm{K}$ vitamini, taze donmuş plazma, noradrenalin başlandı. Takiplerinde deliryuma giren hastada beyin ödemi düşünülerek mannitol ve midazolam infüzyonu başlandı ve 3. düzey yoğun bakım ünitesi olan bir merkeze sevk edildi. Takiplerinde genel durumu düzelen hasta şifa ile taburcu edildi.

\section{Tartışma}

İnvaziv meningokok infeksiyonları tüm dünyada ciddi bir halk sağlığı sorunu olup, her yil tüm dünyada 500.000 yeni vaka görülmekte, 50.000 ölüm ve tüm tedavilere rağmen hastalık sonrası yaşayan kişilerde ise \% 10-20 oranında ciddi sekellere yol açmaktadır ${ }^{8}$. Meningokoksemi hızla ilerleyen farklı klinik tablolarla karşımıza çıkabilmekte ve tanı hastalığın hızlı seyri ile desteklenmektedir. Ateş ve purpurik döküntüler en sık görülen semptomlardır. Ek olarak baş ağrısı, kusma, karın ağrısı gibi semptomlar yanında fizik muayenede ense sertliği de görülebilir. Laboratuvar incelemesinde lökositoz, trombositopeni ve koagülasyon testlerinde anormallik bulunabilir ${ }^{910}$. Şok ve yaygın damar içi pıhtılaşma meningokoksemi kliniğini oluşturan temel patolojilerdir. Yaygın damar içi pıhtılaşmanın derecesine bağlı olarak ekimozlar ve purpura fulminans gelişebilir ve genellikle ölümcüldür ${ }^{11}$. Dolaşım bozukluğuna yol açan önemli bir durum da miyokard tutulumudur ve inotrop başlanması gereklidir .

Booy ve ark. tarafından 1992-1997 yılları arasında İngiltere'de yapılan çalışmada meningokoksemi şüphesinde erken antibiyotik kullanımı ve uygun pediatrik yoğun bakım tedavisinin başlanması ile mortalitenin beş yıllık sürede $\% 23$ 'den $\% 2$ 'lere kadar gerilediği bildirilmiştir $^{12}$. Bu nedenle şüpheli vakalarda uygun sıvı resüsitasyonu, erken antibiyotik ve şok bulguları devam eden hastalarda elektif entübasyon yapılarak yoğun bakımda tedaviye başlanması gereklidir ${ }^{13}$. Hızlı seyirli ve mortalitesinin yüksek olması, erken antibiyotik ve destek tedavilerine başlanmasının prognozda oldukça önemli olması nedeni ile tanısal amaçlı lomber ponksiyon, görüntüleme, transport gibi işlemlerle zaman kaybedilmeden tedaviye başlanmalıdır 7. Penisilin G, ampisilin seftriakson, sefotaksim kullanılabilecek antibiyotiklerdendir ${ }^{12}$.

Vakalarımızın tamamına ön tanı konulduğu andan itibaren septik şok protokolüne uygun şekilde tedavi uygulanmıştır. Ancak birinci vakamızda diğer vakalara göre gecikme olduğu izlenmektedir ve tedaviye cevap alınamamıştır. íkinci vakamızda da tanı anında ağır septik şok bulguları mevcut olmasına rağmen agresif tedavi ile kurtarılmış ancak iki parmağı ampute edilmiştir. Tüm hastalara yeterli sıvı, inotrop, taze donmuş plazma ve $\mathrm{K}$ vitamini uygulanmıştır. îki, üç ve dördüncü hastaların takiplerinde tansiyon arteriyel değerleri normale geldiği için ekokardiyografi yapılmamıştır. Birinci vakada ekokardiyografi yapılması uygun olabilirdi ancak agresif tedavi uygulaması ve portabl ekokardiyografi cihazı bulunmaması nedeni ile yapılamamıştır. Hastalardan hiç birisine lomber ponksiyon uygulanmamıştır. Deliryum bulguları gelişen dördüncü vakaya mannitol ve sedasyon amaçlı midazolam infüzyonu başlanmış ve yoğun bakım ünitemizin ikinci düzey olması nedeni ile ileri merkeze sevk edilmiştir.

Erken tanı ve agresif tedavi uygulanan meningokoksemili hastalarda mortalite önlenebilmektedir. Ateş ve döküntü nedeni ile başvuran ve şok bulguları tespit edilen hastalarda döküntü de bulunması durumunda meningokoksemi düşünülerek erken agresif tedavi başlanması hayati önem taşımaktadır. 


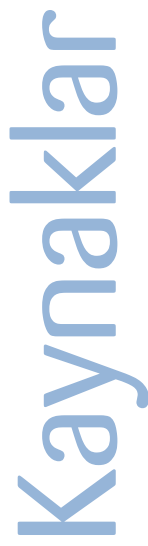

1. Khatami A, Pollard A). The epidemiology of meningococcal disease and the impact of vaccines. Expert Rev Vaccines. 2010;9:285-298.

2. Harrison LH. Epidemiological profile of meningococcal disease in the United States. Clin Infect Dis. 2010;50:S37-44.

3. Halperin SA, Bettinger JA, Greenwood B, Harrison LH, Jelfs J, Ladhani SN, Mclntyre P, Ramsay ME, Sáfadi MA. The changing and dynamic epidemiology of meningococcal disease. Vaccine. 2012; 30 Suppl 2:B26-36.

4. Baines PB, Hart CA. Severe meningococcal disease in childhood. $\mathrm{Br}$ ] Anesthesia 2003; 90:72-83.

5. Kirsch EA, Barton RP, Kitcahen L, Giror BP. Pathophysiology, treatment and outcome of meningococcemia: a review and ecent experience. Pediatr Infect Dis J 1996; 15:967-979.

6. Kurugül Z. Meningokok aşıları. Türk Pediatri Arşivi 2007; 42:51-58.

7. Tamer Özsarı, Gülhan Arvas, Dolunay Karaduman, Bülent Kaya, Kahraman Yakut, Aydoğan Bora. Meningokoksemili Çocukta Erken Tedavi.Van Tip Dergisi 2014: 21; 250-254.

8. Dinleyici EÇ. Yeni Meningokok Aşıları. ANKEM Dergisi 2012; 26:50-60.

9. Nielsen HE, Andersen EA, Andersen J, Böttiger B, Christiansen KM, Daugbjerg $\mathrm{P}$, et al. Diagnostic assessment of haemorrhagic rash and fever. Arch Dis Child 2001; 85:160-165.

10. Welch SB, Nadel S. Treatment of meningococcal infection. Arch Dis Child 2003; 88:608-614

11. Hussain SN, Roussos C. Distrubition of respiratory muscle and organ blood flow during endotoxic shock in dogs. J Appl Physiol 1985; 59:18021808.

12. Booy R, Habibi P, Nadel S, de Munter C, Britto J, Morrison A, et al. Reduction in case fatality rate from meningococcal disease associated with improved healthcare delivery. Arch Dis Child 2001; 85:386-390.

13. İnce E. Çocuklarda Sepsis ve septik şok yönetimi: Antibiyotik tedavisi. ANKEM Derg 2009; 23:258-268.

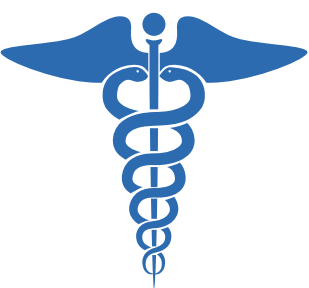

